\title{
Gene Expression Profile by 2,3,7,8-Tetrachlorodibenzo-p-Dioxin in the Liver of Wild- Type (AhR+/+) and Aryl Hydrocarbon Receptor-Deficient (AhR-/-) Mice
}

\author{
Chang Yong YOON ${ }^{1)}$, Misun PARK ${ }^{1)}$, Bang Hyun $\mathrm{KIM}^{1)}$, Ji Yeon PARK ${ }^{1}$, Mun Suk PARK ${ }^{1}$, Youn Kyoung JEONG ${ }^{1)}$, \\ Hyugsung KWON ${ }^{1}$, Hai Kwan JUNG ${ }^{1)}$, HoIl KANG ${ }^{1)}$, Yong Soon LEE ${ }^{2)}$ and Beom Jun $\mathrm{LEE}^{3) *}$ \\ ${ }^{1)}$ Department of Toxicology, National Institute of Toxicological Research, Seoul 122-704, 2)Department of Veterinary Public Health, \\ College of Veterinary Medicine, Seoul National University, Seoul 151-742 and ${ }^{3)}$ Department of Veterinary Public Health, Research \\ Institute of Veterinary Medicine and College of Veterinary Medicine, Chungbuk National University, Cheongju 361-763, Korea
}

(Received 2 February 2006/Accepted 1 March 2006)

\begin{abstract}
Tetrachlorodibenzo- $p$-dioxin (TCDD) is one of the most toxic environmental pollutants that cause various biological effects on mammals. The purpose of our study was to identify the genes involved in hepatotoxicity and hepatocarcinogenesis caused by TCDD. C57BL/6 (AhR+/+, wild type) and B6.129-AhR $<\mathrm{tm} 1 \mathrm{Bra}>/ \mathrm{J}$ (AhR-/-, knock out) mice were injected i.p. with a single treatment of TCDD at the dose of $100 \mu \mathrm{g} / \mathrm{kg}$ body weight. Relative liver weight was significantly increased at $72 \mathrm{hr}$ after TCDD treatment without an apparent histopathological change in AhR $+/+$ mice $(\mathrm{p}<0.05)$. TCDD treatment also significantly increased activity of serum alanine aminotransferase in AhR-/- mice $(\mathrm{p}<0.05)$. The liver was analyzed for gene expression profiles $72 \mathrm{hr}$ later. As compared with AhR/- mice, the expression of 51 genes ( $>3$-fold) was changed in $\mathrm{AhR}+/+$ mice; 28 genes were induced, while 23 genes were repressed. Most of the genes were associated with chemotaxis, inflammation, carcinogenesis, acute-phase response, immune responses, cell metabolism, cell proliferation, signal transduction, and tumor suppression. This study suggests that the microarray analysis of genes in the liver of $\mathrm{AhR}+/+$ and $\mathrm{AhR}-/-$ mice may help to clarify the mechanism of AhR-mediated hepatotoxicity and hepatocarcinogenesis by TCDD.
\end{abstract}

KEY WORDS: gene expression, liver, microarray, TCDD.

J. Vet. Med. Sci. 68(7): 663-668, 2006

Dioxins are a heterogeneous mixture of chlorinated dibenzo- $p$-dioxin and dibenzofuran (PCDD and PCDF) congeners. 2,3,7,8-Tetrachlorodibenzo- $p$-dioxin (TCDD) is considered to be most toxic of the dioxin congeners [37, 43]. TCDD induces a variety of biological responses including induction of cytochrome P-4501A (CYP1A), reproductive and developmental defects, immunotoxicity, thymus atrophy, epothelial disorders, liver damage, wasting syndrome, and cancer $[13,26]$. There is an overflow of data indicating that TCDD is a potent tumor promoter in rat and mouse liver and lung, as well as in mouse skin [20, 27, 31, 36]. TCDD causes tumor promotion by interfering with intracellular signal transduction pathways related to growth factors and cytokines such as transforming growth factor (TGF) and interleukin- $\beta(\mathrm{IL}-1 \beta)[18,20,24,27,31,36,42]$. In addition, TCDD exposure results in reactive oxygen species production and an oxidative stress response in adult and fetal tissues of experimental animals. The reactive oxygen species may in turn oxidize DNA bases, leading to strand breakage or clastogenic effects [31]. Nevertheless, the mechanism of TCDD-induced carcinogenesis is incompletely understood.

TCDD binds to the cytosolic AhR, cytosolic ligand-activated transcription factor. This receptor has the potential to up-regulate and down-regulate the expression of a large number of genes with diverse functions, including those of the Ah gene battery, such as CYP1A1 and CYP1A2 [18, 24,

\footnotetext{
* Correspondence to: Lee, B. J., Department of Veterinary Public Health, College of Veterinary Medicine Chungbuk National University, Cheongju 361-763, Korea.
}

42]. Activation of the AhR is clearly associated with a cellular oxidative stress response, mediated in part by the induction of cytochrome P450 [31]. AhR is widely expressed in mammalian tissues, and it is hypothesized that initial binding to the AhR is linked to the broad spectrum of biochemical and toxic responses observed in laboratory animals and cells exposed to TCDD and other halogenated aromatic contaminants that bind the AhR [27]. Animal experiments revealed that lipophilic TCDD accumulated mostly in the liver and to less extent in fat tissue through absorption from intestine [18]. Concerning the liver, epidemiologic studies in accidently exposed populations revealed hepatotoxicity, and chronic TCDD treatment promoted liver tumor formation in laboratory animals [18]. TCDD has also proved to be positive in cell transformation assays in cultured rodent and human cells [18]. Although several previous studies analyzed the gene expression profiles of hepatocyte cell line cells treated with TCDD using cDNA microarray $[10,42]$ and gene expression profiling approach to in vivo material using serial analysis of gene expression (SAGE) [18], there are few reports on the expression of specific reactive genes against hepatotoxicity of TCDD.

Therefore, in this study to identify the specific genes involved in hepatotoxicity and hepatocarcinogenesis induced by TCDD, we analyzed the differences of gene expression profile in the liver of $\mathrm{AhR}+/+$ and $\mathrm{AhR}-/-$ mice.

\section{MATERIALS AND METHODS}

Chemical: TCDD (purity $>99 \%$ ) was purchased from 
Cerilliant Cambridge Isotope Laboratory, Inc. (Andover, MA, U.S.A.). TCDD was dissolved in acetone and diluted in corn oil as described [15].

Mice: 10 -week-old C57BL/6 male mice $(\mathrm{AhR}+/+)$ and B6.129-Ahr ${ }^{\mathrm{tm} 1 \mathrm{Bra} / \mathrm{J}}$ (AhR-/-) mice were purchased from The Jackson Laboratory (Bar Harbor, MA, U.S.A.) and were allowed 2 weeks for acclimatization. The mice were housed in polyethylene cages containing wood shavings and were given rodent chow and water ad libitum. Mice were housed in rooms maintaining temperature of $21 \pm 1^{\circ} \mathrm{C}$, humidity of $55 \pm 5 \%$, and a 12 -hr light/dark cycle. The experimental protocols were conducted in accordance with internationally accepted principles for laboratory animal use and care as found in the Korea Food and Drug Administration guidelines.

TCDD treatment and sample collection: Three mice of each treatment group were injected i.p. with TCDD at the dose of $100 \mu \mathrm{g} / \mathrm{kg}$ body weight. Control mice received the vehicle alone. At $72 \mathrm{hr}$ after TCDD treatment, blood samples were drawn from the animals at necropsy and activities of alanine aminotransferase (ALT) and aspartate amino transferase (AST) were measured using a clinical chemistry analyzer (Bayer ADIVIA-120 hematology system, Tarrytown, NY, U.S.A.). The terminal body weights and liver weights were recorded. The left lateral lobe of the liver was processed for histopathologic evaluation with H\&E staining. Three small pieces of liver (approximately $20 \mathrm{mg}$ ) from each mouse were stored at $-20^{\circ} \mathrm{C}$ until use of RNA extraction (Ambion Inc, Austin TX, U.S.A.).

Extraction of total RNA: Each sample was placed into 1 $\mathrm{m} l$ of Trizol solution (Invitrogen, Carlsbad, CA, U.S.A.) and homogenized with a polytron homogenizer (Wheaton, Millville, NJ, U.S.A.). Total RNA was separated with Qiagen RNeasy mini kit, according to the protocol described by the manufacturer (Qiagen, Valencia, CA, U.S.A.). The RNA quality was assessed by analyzing the A260/A280 ratio (1.8 or above) and by evaluating the integrity of the $28 \mathrm{~S}$ and $18 \mathrm{~S}$ RNA bands using an Agilent 2100 Bioanalyzer (Agilent Technology, Palo Alto, CA, U.S.A.).

Microarray analysis: First- and second-strand cDNA synthesis, biotin-labeled cRNA synthesis, fragmentation of cRNA and hybridization reactions were performed as a customer service by Affymetrix Inc. (Santa Clara, CA, U.S.A.) and detailed descriptions were found at the Web site, http:// www.affymetrix.com. Briefly, cDNA was synthesized using an one-cycle cDNA synthesis kit from $10 \mu \mathrm{g}$ of each RNA sample. Labeled cRNA was synthesized from cDNA using a GeneChip IVT labeling kit according to the manufacturer's instructions. Approximately $20 \mu \mathrm{g}$ cRNA was then fragmented in a solution of $5 \times$ fragmentation buffer and RNase-free water at $94^{\circ} \mathrm{C}$ for $35 \mathrm{~min}$. Labeled cRNA was hybridized to the GeneChip Test 3 array (Cat. No. Affymetrix 900341) to verify the quality of labeled cRNA. Then cRNA was hybridized by filling with appropriate volume of the clarified hybridization cocktail to the Mouse genome 430A 2.0 array (Cat. No. Affymetrix 900499). The cRNA was hybridized for $16 \mathrm{hr}$ at $45^{\circ} \mathrm{C}$ in the hybridization oven 640 set to $60 \mathrm{rpm}$. After hybridization, the cocktail from the probe array was removed. Then, the probe array was completely washed with the appropriate volume of nonstringent wash buffer and stained with streptavidin phycoerythrin (SAPE) using GeneChip fluidics station 450. The probe array was scanned after the wash and staining protocols with GeneChip Scanner 3,000.

Data analysis and clustering algorithm: For each of the approximately 39,000 genes on the Affymetrix Mouse genome 430A 2.0 array, the data of induction or repression values were analyzed using Affymetrix software analysis (GCOS and DMT). Cluster analysis for gene expression was performed using Cluster 2.1.1 and 'TreeView' version 1.60 software supplied by Stanford University. The clustering was hierarchical using correlation distance as the measurement.

\section{RESULTS}

TCDD-induced liver damage: In wild type $\mathrm{AhR}+/+$ mice, hepatomegaly was reflected by statistically significant increases in relative liver weights at $100 \mu \mathrm{g} / \mathrm{kg}$ body weight (Fig. 1). The relative liver weight in $\mathrm{AhR}+/+$ mice was increased by about $12.0 \%$ compared with the control. However, the relative liver weight in $\mathrm{AhR}-/$ - mice was apparently unaffected. As compared with the control, the activity of ALT in AhR $-/$ - mice was significantly $(\mathrm{p}<0.05)$ increased but that of AST was not significantly changed in both $\mathrm{AhR}+/+$ and AhR-/- mice (Fig. 2). The treatment of TCDD at the dose of $100 \mu \mathrm{g} / \mathrm{kg}$ body weight caused little change in histological examination after $72 \mathrm{hr}$ in the liver of both $\mathrm{AhR}+/+$ and $\mathrm{AhR}-/-$ mice (figure not shown).

TCDD-induced gene expression changes in liver: Microarray analysis was done to determine the hepatic gene expression $72 \mathrm{hr}$ after treatment with TCDD at the dose of $100 \mu \mathrm{g} / \mathrm{kg}$ body weight in $\mathrm{AhR}+/+$ and $\mathrm{AhR}-/-$ mice. As

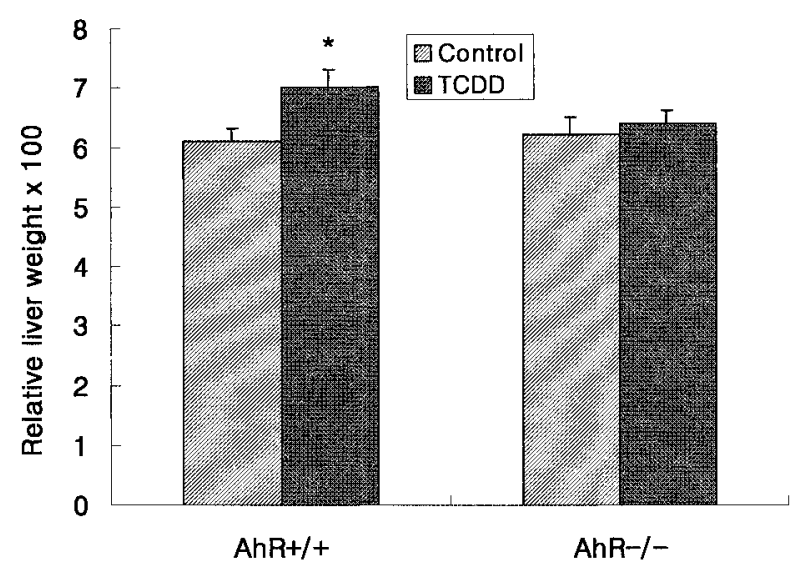

Fig. 1. Effects of TCDD on the relative liver weight in AhR+/+ and $\mathrm{AhR}-/-$ mice. Relative liver weight (\%) was reported as a proportion of total body weight at $72 \mathrm{hr}$ after TCDD treatment at the dose of $100 \mu \mathrm{g} / \mathrm{kg}$ body weight. Bars represent mean \pm SD $(\mathrm{n}=3)$. *Significantly different from the control at $\mathrm{p}<0.05$. 

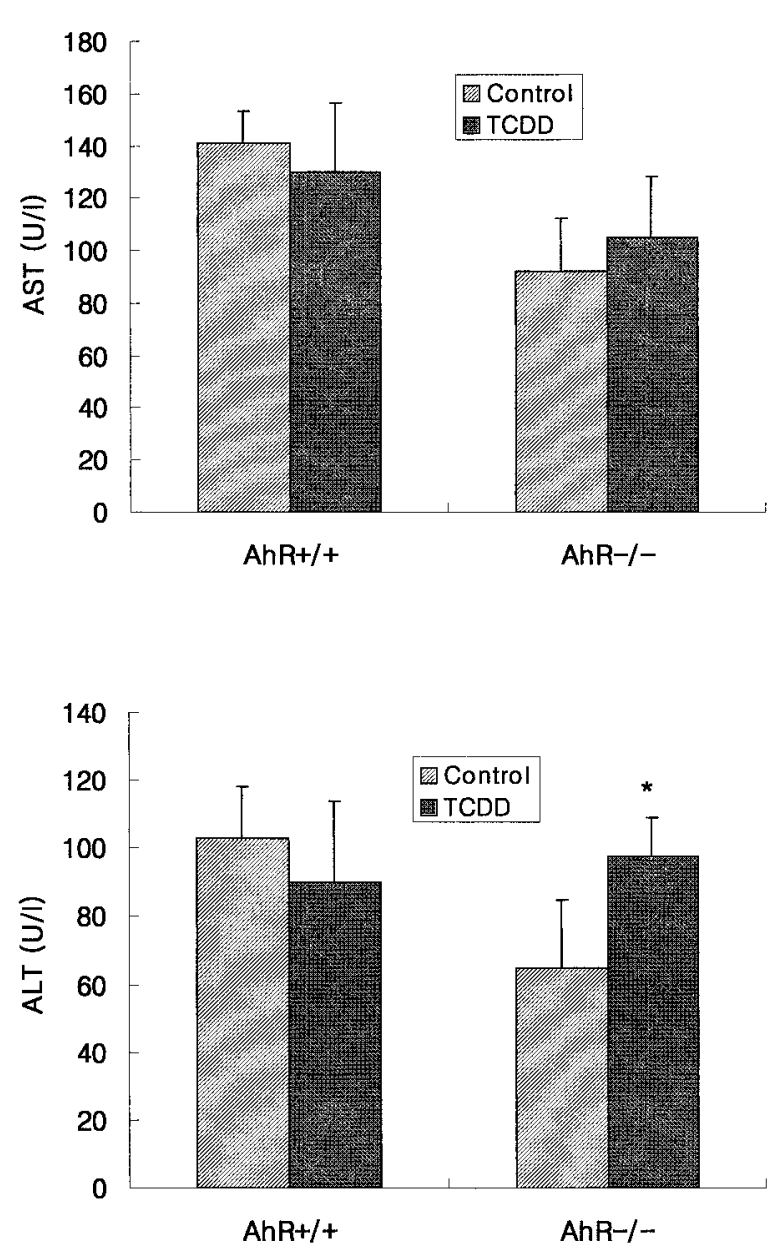

Fig. 2. Effects of TCDD on aspatate aminotransferase (AST) and alanine aminotransferase (ALT) levels in the serum of AhR+/+ and $\mathrm{AhR}-/-$ mice. Blood of mice was collected via retroorbital sinus at $72 \mathrm{hr}$ after TCDD treatment at the dose of $100 \mu \mathrm{g} / \mathrm{kg}$ body weight. Bars represent mean \pm SD $(n=3)$. *Significantly different from the control at $\mathrm{p}<0.05$.

compared with AhR-/- mice, the expression of 51 genes ( $>3$-fold) was changed in AhR $+/+$ mice (Table 1); 28 genes were induced, while 23 genes were repressed (Table 2). The genes intensively up-regulated in only $\mathrm{AhR}+/+$ mice compared with AhR-/- knockout mice were Mcsp, Myc, Hspa2, Atf3, Plcb2, S100a8, Ngp, Saa2, S100a8, S100a9, Cyp4f16, Tnfrsf1b, Csf2rb2, Plcb2,Saa2, Adamdec1,Csf2rb2, Cdgap, H2-D1, Cml5, Kcnq2, and Meig1 (Table 1). Meanwhile, the genes intensively down-regulated in only $\mathrm{AhR}+/+$ mice as compared with AhR-/- mice were Slc13a2, Afmid, Csad, 1810073K19Rik, E130112L23Rik, Upk3b, Vamp1, Tieg1, Erbb2ip, Ngfa, Cdc20, Cabyr, and Lect1 (Table 2).

\section{DISCUSSION}

To identify the specific genes related with AhR-mediated TCDD hepatotoxicity we analyzed the differences of liver gene expression induced by TCDD at the dose of $100 \mu \mathrm{g} / \mathrm{kg}$ body weight in $\mathrm{AhR}+/+$ and $\mathrm{AhR}-/-$ mice. We selected a 72 hr time-point for a variety of reasons. This time point would provide for a complete gene induction response within the liver without the complication of a significant secondary inflammatory response (cellular infiltration) or fibrosis likely to be encountered at later time points [38]. Although histopathological evaluation was performed in our study, apparent lesions in the liver were not observed. Meanwhile, in our preliminary study the treatment of TCDD at the dose of $150 \mu \mathrm{g} / \mathrm{kg}$ body weight caused an increase in the number of apoptotic cells and inflammatory infiltrates in the liver of C57BL/6 mice. In this study, TCDD treatment with $100 \mu \mathrm{g} /$ $\mathrm{kg}$ body weight resulted in a significant increase in the relative liver weight at $72 \mathrm{hr}$ but no histopathological changes were observed. These results are consistent with a recent study that reported increases in liver weights but no alterations in body weight after a single oral dose of TCDD at the concentration up to $100-300 \mu \mathrm{g} / \mathrm{kg}$ [4].

In our study, the levels of enzymes decreased at $72 \mathrm{hr}$ after TCDD treatment in AhR $+/+$ mice, while increased in AhR-/- mice. Fletcher et al. [9] also reported that TCDD treatment caused a decrease in ALT at day 7 in male Sprague-Dawley rats. Meanwhile, Boverhof et al. [4] reported that a significant treatment related alteration were noted in ALT and the levels increased steadily after $24 \mathrm{hr}$ to a maximum of 2.6-fold at $168 \mathrm{hr}$, indicative of mild liver injury in TCDD-treated immature ovarectomized female mice.

In our study, despite the absence of apparent histopathological lesions after treatment with TCDD, changes of gene expression that might be indicative of changes in cellular function were observed. Because of the placement of chlorine atoms on the molecule, TCDD resists metabolic processing and it persists within the cell and produces sustained alterations in gene expression [28, 40]. We suspect that persistence of TCDD is an important factor in producing adverse effects. In our study, we compared the differences of liver gene expression induced or repressed by TCDD treatment between $\mathrm{AhR}+/+$ and $\mathrm{AhR}-/-$ mice. The functions of 28 genes intensively up-regulated ( $>3$-fold) in only $\mathrm{AhR}+/+$ mice compared with $\mathrm{AhR}-/-$ knockout mice were associated with maintenance and stabilization of spermatozoa mitochondria (Mcsp) [1], cell proliferation and transformation related with carcinogenesis (Myc) [14, 17], stress response (Hspa2, Atf3, Plcb2) [2, 11], chemotaxis (S100a8) [35], inflammatory response (Ngp, Saa2, S100a8, S100a9, Cyp4f16, Tnfrsf1b, Csf2rb2, Plcb2) [6, 34, 35], acute-phase response (Saa2) [34] and immune response (Adamdec1,Csf2rb2, Cdgap, H2-D1) [3, 41], cell adhesion (Cml5) [25], neuronal excitation (Kcnq2) [8], cell division (Meig1) [33]. Meanwhile, the functions of 23 genes intensively down-regulated ( $>3$-fold) in only $\mathrm{AhR}+/+$ mice were associated with cell metabolism (Slc13a2, Afmid, Csad, 1810073K19Rik, E130112L23Rik, Upk3b) [16, 19, 23, 30], nerve regeneration (Vamp1) [5], cell growth (Tieg1, Erbb2ip, Ngfa) [21, 22], cell cycle (Cdc20) [32], testis-specific $\mathrm{Ca}^{2+}$-binding protein (Cabyr) [29] and inhibition of 
Table 1. Major genes induced at $72 \mathrm{hr}$ after treatment of TCDD at the dose of $100 \mu \mathrm{g} / \mathrm{kg}$ body weight in $\mathrm{AhR}+/+$ mice in comparison with AhR-/- mice

\begin{tabular}{lllc}
\hline Probe Set ID & \multicolumn{1}{c}{ Gene Title } & Gene Symbol & Fold change \\
\hline 1417101_at & heat shock protein 2 & Hspa2 & 3.15 \\
1417944_at & guanine nucleotide binding protein, gamma 4 subunit & Gng4 & 4.38 \\
1418358_at & mitochondrial capsule selenoprotein & Mcsp & 4.26 \\
1418722_at & neutrophilic granule protein & Ngp & 3.07 \\
1419075_s_at & serum amyloid A 2 & Saa2 & 3.39 \\
1419203_at & gene trap locus F3a & Gtlf3a & 3.99 \\
1419394_s_at & S100 calcium binding protein A8 (calgranulin A) & S100a8 & 5.36 \\
1419476_at & ADAM-like, decysin 1 & Adamdec1 & 3.1 \\
1420800_a_at & potassium voltage-gated channel, subfamily Q, member 2 & Kcnq2 & 3.11 \\
1422988_at & N-sulfoglucosamine sulfohydrolase (sulfamidase) & Sgsh & 3.32 \\
1423410_at & meiosis expressed gene 1 & Meig1 & 3.53 \\
1424811_at & camello-like 5 & Cm15 & 3.04 \\
1424942_a_at & myelocytomatosis oncogene & Myc & 4.35 \\
1426597_s_at & expressed sequence C79267 & C79267 & 3.34 \\
1430172_a_at & cytochrome P450, family 4, subfamily f, polypeptide 16 & Cyp4f16 & 3.19 \\
1430173_x_at & cytochrome P450, family 4, subfamily f, polypeptide 16 & Cyp4f16 & 3.01 \\
1441115_at & DNA segment, Chr 18, ERATO Doi 232, expressed & D18Ertd232e & 3.09 \\
1448296_x_at & & & 3.33 \\
1448756_at & S100 calcium binding protein A9 (calgranulin B) & S100a9 & 6.4 \\
1448951_at & tumor necrosis factor receptor superfamily, member 1b & Tnfrsflb & 3.93 \\
1449233_at & muscle, intestine and stomach expression 1 & Mist1 & 3.31 \\
1449360_at & colony stimulating factor 2 receptor, beta 2, low-affinity & Csf2rb2 & 3.71 \\
1449363_at & activating transcription factor 3 & Atf3 & 3.87 \\
1450162_at & D4, zinc and double PHD fingers, family 3 & Dpf3 & 3.01 \\
1450255_at & Cdc42 GTPase-activating protein & Cdgap & 3.07 \\
1450412_at & transducin (beta)-like 2 & Tb12 & 3.24 \\
1452481_at & phospholipase C, beta 2 & Plcb2 & 3.1 \\
1452544_x_at & histocompatibility 2, D region locus 1 & H2-D1 & 3.31 \\
\hline & & & \\
\hline
\end{tabular}

Table 2. Major genes repressed at $72 \mathrm{hr}$ after treatment of TCDD at the dose of $100 \mu \mathrm{g} / \mathrm{kg}$ body weight in $\mathrm{AhR}+/+$ mice in comparison with $\mathrm{AhR}-/-$ mice

\begin{tabular}{|c|c|c|c|}
\hline Probe Set ID & Gene Title & Gene Symbol & Fold change \\
\hline 1416029_at & TGFB inducible early growth response 1 & Tieg1 & -3.04 \\
\hline $1417867^{-}$at & adipsin & Adn & -4 \\
\hline 1418174 at & D site albumin promoter binding protein & Dbp & -3.2 \\
\hline $1418857^{-}$at & solute carrier family 13, member 2 & Slc13a2 & -3.15 \\
\hline 1419857 at & & & -3.11 \\
\hline 1420942_s_at & & & -3.02 \\
\hline 1421862_a_at & vesicle-associated membrane protein 1 & Vamp1 & -3.09 \\
\hline 1423257_at & & & -7.73 \\
\hline 1427047_at & nucleoporin 188 & Nup188 & -3.33 \\
\hline 1427981_a_at & cysteine sulfinic acid decarboxylase & Csad & -3.1 \\
\hline 1424558_a_at & calcium-binding tyrosine-(Y)-phosphorylation regulated & Cabyr & -3.81 \\
\hline 1431722_a_at & arylformamidase & Afmid & -3.33 \\
\hline 1436643_x_at & RIKEN cDNA $1810073 \mathrm{~K} 19$ gene & 1810073K19Rik & -3.03 \\
\hline 1436768_x_at & RIKEN cDNA E130112L23 gene & E130112L23Rik & -3 \\
\hline 1438211_s_at & D site albumin promoter binding protein & Dbp & -3.69 \\
\hline 1439028_at & & & -3.3 \\
\hline 1439079_a_at & Erbb2 interacting protein & Erbb2ip & -3.08 \\
\hline 1439394_x_at & cell division cycle 20 homolog (S. cerevisiae) & $\mathrm{Cdc} 20$ & -3.09 \\
\hline 1450222_x_at & nerve growth factor, alpha & $\mathrm{Ngfa}$ & -4.07 \\
\hline 1452183_a_at & GTL2, imprinted maternally expressed untranslated mRNA & A Gt12 & -7.17 \\
\hline 1454881_s_at & uroplakin 3B & Upk3b & -3.64 \\
\hline 1456624_at & DNA segment, Chr 11, ERATO Doi 498, expressed & D11Ertd498e & -3.05 \\
\hline 1460258_at & leukocyte cell derived chemotaxin 1 & Lect1 & -3.88 \\
\hline
\end{tabular}

tumor growth (Lect1) [12].

The results reported here suggest that toxicity may reflect sustained alterations in the expression of many genes and that the changes reflect both direct and indirect effects of 
TCDD. Recently, several groups reported gene expression profiles in vitro and in vivo models exposed to TCDD. Using cDNA microarray technology, Frueh et al. (2001) reported that numerous induced genes of human liver HepG2 cell by TCDD treatment appear to have functions in cell growth and proliferation, cell adhesion, antioxidative activity, acute-phase responses, and these results may be associated with maintaining homeostasis against TCDD exposure. Using pathway-specific cDNA arrays to detect the transcriptional signature induced by TCDD in C57BL/6 mice after intraperitoneal injection with $50 \mu \mathrm{g} / \mathrm{kg}$ body weight of TCDD, TCDD altered the expression of a large array of genes involved in apoptosis and angiogenesis [42]. The other experiment using serial analysis of gene expression (SAGE) technique revealed that in C57BL/6 mice the genes involved in hepatotoxicity and hepatocarcinogenesis induced by TCDD treatment with a single oral dose of 20 $\mu \mathrm{g} / \mathrm{kg}$ body weight were not only the genes encoding drug metabolizing enzymes and stress response genes but also a wide variety of genes encoding cytoskeleton related proteins, signal transduction, and plasma proteins [18]. Regarding the liver genes involved in xenobiotics metabolism or stress response, signal transduction, cell cycle and cell proliferation, the expression profiles of these studies were mostly consistent with our results obtained by using the oligonucleotide DNA microarray chip (Affymetrix) in vivo mouse model.

In our study, the most significant gene changed by TCDD in both $\mathrm{AhR}+/+$ and $\mathrm{AhR}-/-$ knockout mice was Cypla1 which was up-regulated over 100 -fold by TCDD, although the change was not shown in our comparative data, indicating that the difference from change in gene expression by TCDD between $\mathrm{AhR}+/+$ mice and $\mathrm{AhR}-/-$ mice was less than 3-fold. Most compounds that are known to induce Cypla1 have been shown be the ligand for the AhR [39]. However, there are reports that Cyplal induction can be seen with compounds that are not apparent AhR ligands based on their inability to compete with TCDD for receptor binding [39]. In addition, there are different hypotheses proposed for how Cypla1 could be induced by mechanisms that do not involve in the AhR [7]. Based on the similarity of effect of TCDD on Cyplal expression of both AhR+/+ and AhR-/- mice, it is likely that there are other signaling pathways for Cypla1 induction though more studies would be required to conclusively understand those.

Overall, the results of our study imply that cellular responses to TCDD is notably complex and is associated with alterations in the expression of a large array of genes, and can provide a fingerprint genes that may help to clarify the mechanism of TCDD effects on hepatic genotoxicity and carcinogenesis.

ACKNOWLEDGMENT. This work was financially supported by the Korea Food and Drug Administration Grant KFDA-04131-EDS-299.

\section{REFERENCES}

1. Aho, H., Schwemmer, M., Tessman, D., Murphy, D., Mattei, G., Engel, W. and Adham, I. M. 1996. Isolation, expression, and chromosomal localization of the human mitochondrial capsule selenoprotein gene (MCSP). Genomics 32: 184-190.

2. Atta-ur-Rahman, Harvey, K. and Siddiqui, R. A. 1999. An autocrine inflammatory mediator. Curr. Pharm. Des. 5: 241253.

3. Bates, E. E., Fridman, W. H. and Mueller, C. G. 2002. The ADAMDEC1 (decysin) gene structure: evolution by duplication in a metalloprotease gene cluster on chromosome $8 \mathrm{p} 12$. Immunogenetics 54: 96-105.

4. Boverhof, D. R., Burgoon, L. D., Tashiro, C., Chittim, B., Harkema, J. R., Jump, D. B. and Zacharewski, T. R. 2005. Temporal and dose-dependent hepatic gene expression patterns in mice provide new insights into TCDD-mediated hepatotoxicity. Toxicol. Sci. 85: 1048-1063.

5. Che, Y. H., Yamashita, T. and Tohyama, M. 2002. Changes in mRNA for VAMPs following facial nerve transection. $J$. Chem. Neuroanat. 24: 147-152.

6. Cui, X., Kawashima, H., Barclay, T. B., Peters, J. M., Gonzalez, F. J., Morgan, E. T. and Strobel, H. W. 2001. Molecular cloning and regulation of expression of two novel mouse CYP4F genes: expression in peroxisome proliferator-activated receptor alpha-deficient mice upon lipopolysaccharide and clofibrate challenges. J. Pharmacol. Exp. Ther. 296: 542-550.

7. Delescluse, C., Lemaire, G., Sousa, G.. D. and Rahmani, R. 2000. Is CYP1A1 induction always related to AHR signaling pathway. Toxicology 153: 73-82.

8. Etxeberria, A., Santana-Caxtro, I., Regalado, M.P., Aivar, P. and Villarroel, A. 2004. Three mechanisms underlie KCNQ2/3 heteromeric potassium M-channel potentiation. J. Neurosci. 24: 9146-9152.

9. Fletcher, N., Wahlstrom, D., Lundberg, R., Nilsson, C. B., Nilsson, K. C., Stockling, K., Hellmold, H. and Hakansson, H. 2005. 2,3,7,8-Tetrachlorodibenzo-p-dioxin (TCDD) alters the mRNA expression of critical genes associated with cholesterol metabolism, bile acid biosynthesis, and bile transport in rat liver: A microarray study. Toxicol. Appl. Phamacol. 207: 1-24.

10. Frueh, F. W., Hayashibara, K. C., Brown, P. O. and Whitlock Jr, J. P. 2001. Use of cDNA microarrays to analyze dioxininduced changes in human liver gene expression. Toxicol. Lett. 122: 189-203.

11. Hartman, M. G., Lu, D., Kim, M. L., Kociba, G. J., Shukri, T., Buteau, J., Wang, X., Frankel, W. L., Guttridge, D., Prentki, M., Grey, S. T., Ron, D. and Hai, T. 2004. Role for activating transcription factor 3 in stress-induced beta-cell apoptosis. Mol. Cell Biol. 24: 5721-5732.

12. Hayami, T., Shukunami, C., Mitsui, K., Endo, N., Tokunaga, K., Kondo, J., Takahashi, H. E. and Hiraki, Y. 1999. Specific loss of chondromodulin-1 gene expression in chondrosarcoma and the suppression of tumor angiogenesis and growth by its recombination protein in vivo. FEBS Lett. 458: 436-440.

13. Huang P., Ceccatelli. S., Hakansson. H., Grandison. L. and Rannug. A. 2002. Constitutive and TCDD-induced expression of Ah receptor-responsive genes in the pituitary. Neurotoxicology 23: 783-93.

14. Kabilova, T. O., Chernolovskaya, E. L., vladimirova, A. V. and Vlassov, V. V. 2004. Silencing of c-myc expression in tumor cells by siRNA. Nucleosides Nucleotides Nucleic Acids $\mathbf{2 3}$ : 867-872.

15. Kamath, A. B., Xu, H., Nagarkatti, P. S. and Nagarkatti, M. 
1997. Evidence for the induction of apoptosis in thymocytes by 2,3,7,8-tetrachlorodibenzo-p-dioxin in vivo. Toxicol. Appl. Pharmacol. 142: 367-377.

16. Kishimoto, T., Kokura, K., Nakadai, T., Miyazawa, Y., Wakamatsu, T., Makino, Y., Nakamura, T., Hara, E., Oda, K., Muramatsu, M. and Tamura, T. 1996. Overexpression of cyteine sulfinic acid decarboxylase stimulated by hepatocarcinogenesis results in autoantibody production in rat. Cancer Res. 56: 5230-5237.

17. Knies-Bamforth, U. E., Fox, S. B., Poulsom, R., Evan, G. I. and Harris, A. L. 2004. c-Myc interacts with hypoxia to induce angiogenesis in vivo by a vascular endothelial growth factordependent mechanism. Cancer Res. 64: 6563-6570.

18. Kurachi, M., Hashimoto, S., Obata, A., Nagai, S., Nagahata, T., Inadera, H., Sone, H., Tohyama, C., Kaneko, S., Kobayashi, K. and Matsushima, K. 2002. Identification of 2,3,7,8-tetrachlorodibenzo-p-dioxin-responsive genes in mouse liver by serial analysis of gene expression. Biochem. Biophys. Res. Commun. 292: 368-377.

19. Markovich, D. and Murer, H. 2004. The SLC13 gene family of sodium sulphate/carboxylate cotransporters. Pflugers Arch. 447: 594-602.

20. Martinez, J. M., Afshari, C. A., Bushel, P. R., Masuda, A., Takahashi, T. and Walker, N. J. 2002. Differential toxicogenomic responses to 2,3,7,8-tetrachlorodibenzo-p-dioxin in malignant and nonmalignant human airway epithelial cells. Toxicol. Sci. 69: 409-423.

21. Menard, S., Casalini, P., Campiglio, M., Pupa, S. M. and Tagliabue, E. 2004. Oncogenic protein tyrosine kinases role of HER2/neu in tumor progression and therapy. Cell. Mol. Life Sci. 61: 2965-2978.

22. Mitsumoto, M., Mitsumoto, A. and Demple, B. 2003. Nitric oxide-mediated upregulation of TGF-beta-inducible early response gene-1 (TIEG1) in human fibroblasts by mRNA stabilization independent of TGF-beta. Free Radic. Biol. Med. 34: 1607-1613.

23. Osman, I., Kang, M., Lee, A., Deng, F. M., Polsky, D., Mikhail, D., Mikhail, M., Chang, C., David, D. A., Mitra, N., Wu, X. R., Sun, T. T. and Bajorin, D. F. 2004. Detection of circulating cancer cells expressing uroplakins and epidermal growth factor receptor in bladder cancer patients. Int. J. Cancer 111: 934-939.

24. Patterson, R. M., Stachlewitz, R. and Germolec, D. 2003. Induction of apoptosis by 2,3,7,8-tetrachlorodibenzo-p-dioxin following endotoxin exposure. Toxicol. Appl. Pharmacol. 190: 120-134.

25. Popsueva, A. E., Luchinskaya, N. N., Ludwig, A. V., Zinovjeva, O. Y., Poteryaev, D. A., Feigelman, M. M., Ponomarev, M. B., Berekelya, L. and Belyavsky, A. V. 2001. Overexpression of camello, a member of a novel protein family, reduces blastomere adhesion and inhibits gastrulation in Xenopus laevis. Dev. Biol. 234: 483-496.

26. Puga. A., Maier. A. and Medvedovic. M. 2000. The transcriptional signature of dioxin in human hepatoma HepG2 cells. Biol. Pharmacol. 60: 1129-1142.

27. Safe, S. H. 2001. Molecular biology of the Ah receptor and its role in carcinogenesis. Toxicol. Lett. 120: 1-7.

28. Safe, S. H. 1986. Comparative toxicology and mechanism of action of polychlorinated dibenzo-p-dioxins and dibenzofurans. Annu. Rev. Pharmacol. Toxicol. 26: 371-399.

29. Sen, B., Mandal, A., Wolkowicz, M. J., Kim, Y. H., Reddi, P.
P., Shetty, J., Bush, L. A., Flickinger, C. J. and Herr, J. C. 2003. Splicing in murine CABYR and its genomic structure. Gene 310: 67-78.

30. Serrano, A. E. Jr. and Nagayama, F. 1991. Inhibition studies on liver arylformamidases of rainbow trout and cattle. Comp. Biochem. Physiol. B. 99: 281-285.

31. Shertzer, H. G., Clay, C. D., Genter, M. B., Schenider, S. N., Nebert, D. W. and Dalton, T. P. 2004. CYP1A2 protects against reactive oxygen production in mouse liver microsomes. Free Radic. Biol. Med. 36: 605-617.

32. Sohn, J., Kristjansdottir, K., Safi, A., Parker, B., Kiburz, B. and Rudolph, J. 2004. Remote hot spots mediate protein substrate recognition for the Cdc25 phosphatase. Proc. Natl. Acad. Sci. U.S.A. 101: 16437-16441.

33. Steiner, R., Ever, L. and Don, J. 1999. MEIG1 localizes to the nucleus and binds to meiotic chromosomes of spermatocytes as they initiate meosis. Dev. Biol. 216: 635-645.

34. Stevens, F. J. 2004. Hypothetical structure of human serum amyloid A protein. Amyloid 11: 71-80.

35. Striz, I. and Trebichavsky, I. 2004. Calprotectin-a pleiotropic molecule in acute and chronic inflammation. Physiol. Res. 53: 245-253.

36. Viluksela, M., Bager. Y., Tuomisto. J. T., Sche. G., Unkila. M., Pohjanvirta. R., Flodstrom. S., Kosma. V. M., Maki-Paakkaneu. J., Vartiainen. T., Klimm C., Schramm. K. W., Warngard. L. and Tuomisto. J. 2000. Liver tumor-promoting activity of 2,3,7,8-tetrachlorodibenzo-p-dioxin (TCDD) in TCDD-sensitive and TCDD-resistant rat strains. Cancer Res. 60: 69116920.

37. Walker, N. J., Portier, C. J., Lax, S. F., Crofts. F. G. and Li, Y., Lucier. G. W. and Sutter. T. R. 1999. Characterization of the dose-response of CYP1B1, CYP1A1, and CYP1A2 in the liver of female Sprague-Dawley rats following chronic exposure to 2,3,7,8-tetrachlorodibenzo-p-dioxin. Toxicol. Applied Pharmacol. 154: 279-286.

38. Waring, J. F., Gum, R., Morfitt, D., Jolly, R. A., Ciurlionis, R., Heindel, M., Gallenberg, L., Buratto, B. and Ulrich, R. G. 2001. Clustering of hepatotoxins based in mechanism of toxicity using gene expression profiles. Toxicol. Appl. Pharmacol. 175: $28-42$.

39. Waring, J. F., Jolly, R. A., Lum, P. Y., Praestgaard, J. T., Morfitt, D. C., Buratto, B., Roberts, C., schadt, E. and Ulrich, R.G., 2002. Identifying toxic mechanisms using DNA microarrays: evidence that an experimental inhibitor of cell adhesion molecule expression signals through the aryl hydrocarbon nuclear receptor. Toxicology 181-182: 537-550.

40. Whitlock, J. P. Jr. 1993. Mechanistic aspects of dioxin action. Chem. Res. Toxicol. 6: 754-763.

41. Yang, J., Kanter, G., Voloshin, A., Levy, R. and Swartz, J. R. 2004. Expression of active murine granulocyte-macrophage colony-stimulating factor in an Escherichia coli cell-free system. Biotechnol. Prog. 20: 1689-1696.

42. Zeytun, A., Mckallip, R. J., Fisher, M., Camacho, I., Nagarkatti, M. and Nagarkatti, P. S. 2002. Analysis of 2,3,7,8-tetrachlorodibenzo-p-dioxin-induced gene expression profile in vivo using pathway-specific cDNA arrays. Toxicology 178: 241-260.

43. Zodrow. J. M., Stegemal. J. J. and Tanguay. R. L. 2004. Histological analysis of acute toxicity of 2,3,7,8-tetrachlorodibenzop-dioxin (TCDD) in zebrafish. Aquatic Toxicol. 66: 25-38. 